University of Nebraska - Lincoln

DigitalCommons@University of Nebraska - Lincoln

Faculty Papers and Publications in Animal

Science

Animal Science Department

1969

\title{
Levels of Calcium and Phosphorus for Growing-Finishing Swine
}

G. W. Libal

University of Nebraska-Lincoln

E. R. Peo, Jr.

University of Nebraska-Lincoln

R. P. Andrews

University of Nebraska-Lincoln

P. E. Vipperman, Jr.

University of Nebraska-Lincoln

Follow this and additional works at: https://digitalcommons.unl.edu/animalscifacpub

Part of the Animal Sciences Commons

Libal, G. W.; Peo, Jr., E. R.; Andrews, R. P.; and Vipperman, Jr., P. E., "Levels of Calcium and Phosphorus for Growing-Finishing Swine" (1969). Faculty Papers and Publications in Animal Science. 631.

https://digitalcommons.unl.edu/animalscifacpub/631

This Article is brought to you for free and open access by the Animal Science Department at DigitalCommons@University of Nebraska - Lincoln. It has been accepted for inclusion in Faculty Papers and Publications in Animal Science by an authorized administrator of DigitalCommons@University of Nebraska - Lincoln. 


\title{
LEVELS OF CALCIUM AND PHOSPHORUS FOR GROWING-FINISHING SWINE ${ }^{1}$
}

\author{
G. W. Libal, E. R. Peo, Jr., R. P. Andrews and P. E. Vipperman, Jr. ${ }^{2}$ \\ Nebraska Agriculture Experiment Station, Lincoln
}

$\mathrm{T}$ THE calcium and phosphorus requirements of growing-finishing swine have not been satisfactorily resolved. Recently it was suggested that levels of calcium and phosphorus needed in diets of growing-finishing (G-F) swine for optimum growth and feed conversion may be different from those needed for optimum bone development (Miller et al, 1960; Lloyd et al., 1961; Rutledge et al., 1961; Combs et al., 1966). The problem of determining calcium and phosphorus requirements is further magnified by the observation of Chapman et al. (1955) that G-F swine do not utilize plant phosphorus as efficiently as inorganic phosphorus. In addition, Chapman et al. (1962) reported that phosphorus had a greater effect on growth, feed conversion and bone development than calcium and that the calcium-phosphorus ratio is more important than dietary levels of phosphorus for optimum over-all performance.

Besides these aspects of calcium-phosphorus nutrition, a possible relationship of calcium and phosphorus to the disease atrophic rhinitis (AR) has been reported by Brown et al. (1966).

The purpose of the research presented in this paper was to determine further the relationship of levels and ratios of calcium and phosphorus to rate of gain, feed conversion and bone characteristics of G-F swine. In addition, the possible relationship of calcium and phosphorus to AR was investigated.

\section{Materials and Methods}

Animals. In Experiment 1, 80 Yorkshire $X$ Hampshire crossbred pigs averaging $35 \mathrm{~kg}$. of bodyweight were randomly assigned within sex and weight groups to two replications of five dietary treatments. Each replication contained four barrows and four gilts. The study

\footnotetext{
1 Published with the approval of the Director as Paper No. 2411, Journal Series. Nebr. Agr. Exp. Sta.

2 Department of Animal Science. Acknowledgement is made to $P$. J. Cunningham and associates for assistance in caring for the experimental animals. T. W. Dunn for assistance in colfor the experimental animals. J. W. Dunn for assistance in colfor providing the vitamin premix used in the experimental for $p$
}

lasted 84 days and was conducted during the summer months.

In Experiment 2, 40 Yorkshire $\times$ Hampshire crossbred pigs averaging $27.4 \mathrm{~kg}$. of bodyweight were randomly assigned within sex and weight groups to five experimental diets with two replications. Each replication consisted of three gilts and two barrows. The study lasted 83 days and was conducted during the winter months.

In Experiment 3, 60 Yorkshire $\times$ Hampshire crossbred pigs averaging $22.4 \mathrm{~kg}$. were randomly assigned to five treatments with one replication of barrows and one of gilts. The experiment lasted 98 days and was conducted during the summer months.

The pigs of all three experiments were housed in pens made up of open-fronted sheds with concrete runways. Each pen was equipped with a self-feeder and automatic waterer. Straw was used for bedding in the winter, and shade and sprinklers were provided during the summer. Pig weights and feed data were collected at 2-wk. intervals.

Diets. Composition of the diets and the treatment variables are shown in table 1 for the first two experiments and in table 2 for experiment 3 . A standard $14 \%$ protein cornsoybean meal formulation was used as the basal diet and was fed for the entire experimental period. Calcium and phosphorus levels and ratios were the dietary variables and were developed with dicalcium phosphate, calcium carbonate and monosodium phosphate.

In the first experiment, the calcium-phosphorus levels varied from $0.40 \%$ of the diet to $0.90 \%$ with approximate ratios of $1: 1$ with $0.40 \% \mathrm{Ca} ; 1.6: 1,1: 1$ and $0.7: 1$ with $0.65 \%$ $\mathrm{Ca}$ and $1: 1$ with $0.9 \% \mathrm{Ca}$ (treatments $\mathrm{A}, \mathrm{B}$, $\mathrm{C}, \mathrm{D}$ and $\mathrm{E}$, respectively).

In the second experiment, two levels of calcium $(0.35 \%$ and $0.65 \%)$ were fed with varying levels of phosphorus in an attempt to create an imbalance between the two. The respective dietary calcium-phosphorus ratios were $1: 3,1: 4$, with $0.35 \% \mathrm{Ca}$ and $1: 1,1: 3$ and $1: 2$ with $0.65 \%$ calcium (treatments $F$, $\mathrm{G}, \mathrm{H}, \mathrm{I}$ and $\mathrm{J}$, respectively). 
TABLE 1. COMPOSITION OF EXPERIMENTAL DIETS ${ }^{*}$

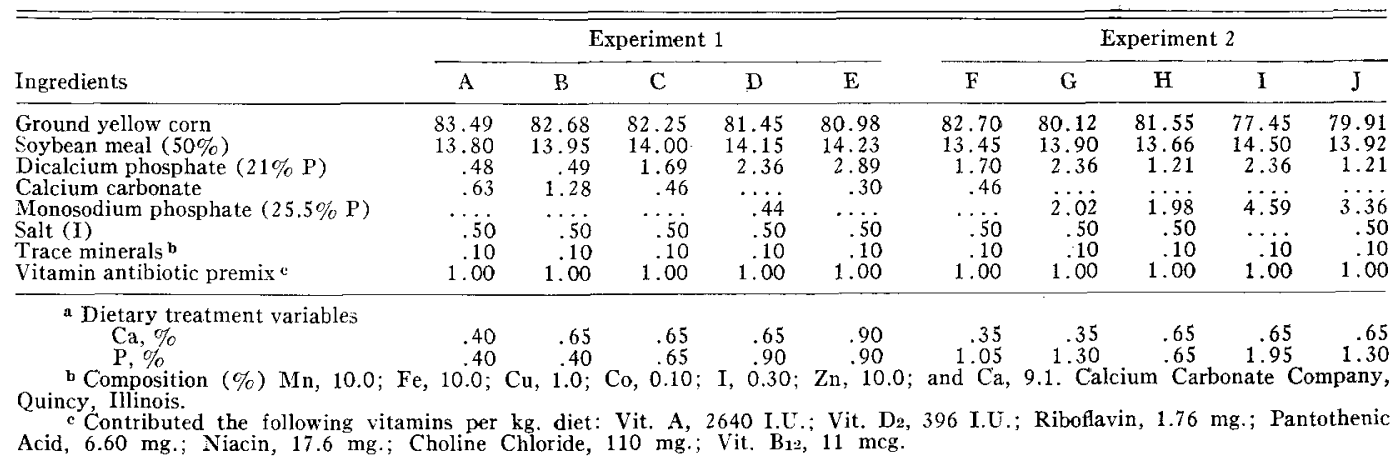

In experiment 3 , the dietary variable was phosphorus level. Calcium was held constant at $0.35 \%$ with phosphorus increased from $0.30 \%$ to $0.70 \%$ at $0.10 \%$ increments (treatments $\mathrm{K}, \mathrm{L}, \mathrm{M}, \mathrm{N}$ and $\mathrm{O}$ ). All of the phosphorus in diet $\mathrm{K}(0.30 \% \mathrm{P})$ originated from corn and soybean meal; i.e., no inorganic phosphorus was added to this diet. Of the total phosphorus in diets $\mathrm{L}, \mathrm{M}, \mathrm{N}$ and $\mathrm{O}, 25,40$, 50 and $57 \%$ was from added inorganic P. Monosodium phosphate was used as the source of inorganic phosphorus.

When the pigs weighed approximately 95 $\mathrm{kg}$., they were shipped to the George A. Hormel Packing Plant, Fremont, Nebraska, for slaughter. Each animal was properly identified and the carcasses were examined by a research veterinarian for gross evidence of AR. Atrophy of the turbinates resulting in a separation of more than $6 \mathrm{~mm}$. between the turbinate and the septum of the nasal passage was considered as suspect for AR. The turbinates of suspects were retained for detailed gross pathological studies.

The hind legs were collected from the carcasses of the pigs and the fourth metatarsal

TABLE 2. COMPOSITION OF EXPERIMENTAL DIETS $^{*}$

\begin{tabular}{|c|c|c|c|c|c|}
\hline \multirow[b]{2}{*}{ Ingredients } & \multicolumn{5}{|c|}{ Experiment 3} \\
\hline & K & L & M & $\mathrm{N}$ & 0 \\
\hline Ground yellow corn & 84.47 & 83.97 & 83.47 & 83.97 & 82.47 \\
\hline Soybean meal $(50 \%)$ & 13.10 & 13.20 & 13.30 & 13.40 & 13.50 \\
\hline Calcium carbonate & .83 & .83 & .83 & .83 & .83 \\
\hline \multirow{2}{*}{$\begin{array}{l}\text { Monosodium } \\
\text { phosphate }(25.5 \% \mathrm{P})\end{array}$} & & & & & \\
\hline & & .40 & .80 & 1.20 & 1.60 \\
\hline Salt (I) & .50 & .50 & .50 & .50 & .50 \\
\hline $\begin{array}{l}\text { Trace minerals b } \\
\text { Vitamin antibiotic }\end{array}$ & .10 & .10 & .10 & .10 & .10 \\
\hline premix $^{\mathrm{c}}$ & 1.00 & 1.00 & 1.00 & 1.00 & 1.00 \\
\hline \multicolumn{6}{|c|}{ Dietary treatment variables } \\
\hline \multirow{2}{*}{$\begin{array}{l}\mathrm{Ca}, \% \\
\mathrm{P}, \% \\
\text { Added Inorganic }\end{array}$} & .35 & .35 & .35 & .35 & .35 \\
\hline & .30 & .40 & .50 & .60 & .70 \\
\hline $\begin{array}{l}\text { P, o of Total } \\
\text { e Composition same } \\
\text { Composition same }\end{array}$ & $\begin{array}{l}0 \\
\text { for } \mathrm{Ex} \\
\text { for } \mathrm{Ex}\end{array}$ & 25 & $\begin{array}{l}40 \\
1 \text { anc } \\
1 \text { anc }\end{array}$ & 2. & 57 \\
\hline
\end{tabular}

bone was excised for determining the effect of calcium-phosphorus levels on bone characteristics. Standard procedures as outlined in A.O.A.C. (1960) were used to determine weight and percent ash of the moisture-free, fat-free 4th metatarsal bone.

Bone breaking strength (BKS) was determined with a Fred S. Carver Laboratory Press. A hydraulic jack system was used to deliver a uniform increasing force up to the time of breakage. The amount of pressure required to apply the force (bridge-fulcrum system) to break the bone was read directly from a dial.

The data were analyzed by analyses of variance methods as outlined by Steel and Torrie (1960).

\section{Results and Discussion}

The results of experiment 1 are shown in table 3. No significant differences were observed in average daily gain, feed intake or feed conversion due to dietary treatments. There was a significant $(\mathrm{P}<.05)$ difference in BKS between pigs on diets $A$ and $D$. These diets represented $0.40 \%$ calcium and $0.40 \%$ phosphorus and $0.65 \%$ calcium and $0.90 \%$ phosphorus, respectively.

A summary of the gain and feed conversion data for Experiment 2 is also shown in table 3 . No significant differences were observed in average daily gain, daily feed intake and feed conversion for diets $F, G, H$ and $J$.

Six weeks after initiation of the experiments one pig on treatment I died from acute renal insufficiency. Subsequent blood urea nitrogen values determined on the remaining pigs on treatment $I$ indicated evidence also of renal malfunction. Thus, the pigs were terminated from the study.

There was a significant $(\mathrm{P}<.005)$ treat- 
TABLE 3. EFFECT OF LEVELS OF CALCIUM AND PHOSPHORUS ON GAIN, FEED CONVERSION AND BONE CHARACTERISTICS OF G-F SWINE

\begin{tabular}{|c|c|c|c|c|c|c|c|c|c|c|}
\hline \multirow[b]{2}{*}{ Treatments } & \multicolumn{5}{|c|}{ Experiment 1} & \multicolumn{5}{|c|}{ Experiment 2} \\
\hline & A & B & C & $\mathrm{D}$ & $\mathbf{E}$ & $\mathrm{F}$ & G & $\mathbf{H}$ & $I$ & $J$ \\
\hline $\begin{array}{l}\mathrm{Ca} \% \\
\mathrm{P} \%\end{array}$ & $\begin{array}{l}0.40 \\
0.40\end{array}$ & $\begin{array}{l}0.65 \\
0.40\end{array}$ & $\begin{array}{l}0.65 \\
0.65\end{array}$ & $\begin{array}{l}0.65 \\
0.90\end{array}$ & $\begin{array}{l}0.90 \\
0.90\end{array}$ & $\begin{array}{l}0.35 \\
1.05\end{array}$ & $\begin{array}{l}0.35 \\
1.30\end{array}$ & $\begin{array}{l}0.65 \\
0.65\end{array}$ & $\begin{array}{l}0.65 \\
1.95\end{array}$ & $\begin{array}{l}0.65 \\
1.30\end{array}$ \\
\hline No. pigs per treatment a & 16 & 16 & 16 & 16 & 16 & 10 & 10 & 10 & 10 & 10 \\
\hline \multicolumn{11}{|l|}{ Criterion } \\
\hline $\begin{array}{l}\text { Av. daily gain, kg } \\
\text { Feed intake, kg./day } \\
\text { Gain } / \text { feed } \\
\text { Bone breaking strength } \mathrm{kg} . / \mathrm{cm}^{2} \\
\text { Bone wt., gm. } \\
\text { Bone ash, \% }\end{array}$ & $\begin{array}{l}.73 \\
2.30 \\
.32 \\
7.4 c \\
\cdots \\
\cdots\end{array}$ & $\begin{array}{l}.74 \\
2.41 \\
.32 \\
8.0 \\
\cdots \\
\cdots\end{array}$ & $\begin{array}{l}.78 \\
2.46 \\
.32 \\
8.3 \\
\ldots \\
\cdots\end{array}$ & $\begin{array}{l}.77 \\
2.48 \\
.31 \\
9.30 \\
\ldots \\
\ldots\end{array}$ & $\begin{array}{l}.79 \\
2.51 \\
.32 \\
8.4 \\
\cdots \\
\cdots\end{array}$ & $\begin{array}{l}.80 \\
2.88 \\
.28 \\
10.4 \\
12.2 \\
57.4\end{array}$ & $\begin{array}{r}.72 \\
2.77 \\
.26 \\
11.1 \\
12.6 \\
57.1\end{array}$ & $\begin{aligned} & .77 \\
& 2.65 \\
& 15.29 \\
& 15.6 \\
& 14.7 \\
& 57.8\end{aligned}$ & $\begin{array}{l}\ldots \ldots b \\
\cdots \cdots \\
\cdots \\
\cdots \cdots\end{array}$ & $\begin{array}{r}.78 \\
2.83 \\
.27 \\
11.8^{d} \\
13.6^{\circ} \\
57.5\end{array}$ \\
\hline
\end{tabular}

a Exp. 1: Two reps, 8 pigs/pen; int. wt. 35 kg. Exp. $2:$ Two reps, 5 pigs/pen; int. wt. 27.4 kg.

b Surviving pigs removed from experiment at end of 6 weeks because pigs showed evidences of renal insufficiencies.

a Over-all treatment effect sig. $P<.005$.

Difference between $F$ and $G$ is. $\dot{H}$ and $J$ sig. $P<.005$.

e Over-all treatment effect sig. $\mathrm{P}<005$

Difference between $F$ and $G$ vs. $H$ and $J$ sig. $P<.005$.

ment effect on bone breaking strength (BKS) and bone weight due to levels of calcium and phosphorus in the diet. Both BKS and bone weight, $\mathrm{kg} . / \mathrm{cm} .{ }^{2}$ and $\mathrm{kg}$., respectively, were significantly higher $(\mathrm{P}<.005)$ in diets $\mathrm{H}$ and $\mathrm{J}$ which contained $0.65 \%$ calcium. The correlation between $\mathrm{BKS}$ and bone weight was 0.82 .

In Experiment 3, increasing inorganic phosphorus in $0.10 \%$ increments from $0.30 \%$ to $0.70 \%$ of the diet resulted in a $(\mathrm{P}<.10)$ linear effect on average daily gain. The addition of inorganic phosphorus also had a significant linear $(\mathrm{P}<.005)$ and a quadratic $(\mathrm{P}<.10)$ effect on daily feed intake. Feed intake was maximum at the $0.60 \%$ phosphorus level in which $50 \%$ of the phosphorus was from an inorganic source.

BKS varied from an average of $9.6 \mathrm{~kg} . / \mathrm{cm} .{ }^{2}$ for pigs fed diet $\mathrm{K}$ to $15 \mathrm{~kg} . / \mathrm{cm} .^{2}$ for pigs on diet $\mathrm{N}$. The treatment effect was significant $(\mathrm{P}<.05)$. There was also a linear $(\mathrm{P}<.10)$ effect on BKS from the addition of equal increments of phosphorus to the basal diets. Bone weight followed the same pattern as BKS. The correlation between BKS and bone weight was 0.66 .

Sixty-four of the 80 pigs in Experiment 1 were examined for the possibility of erosion of turbinates indicating AR. All of the pigs examined proved negative for evidence of AR.

In Experiment 2, all 40 pigs were examined at slaughter. Two pigs, one each from Diet $\mathrm{F}$ and Diet J were listed as suspect for AR by gross examination at the Packing Plant because the turbinates deviated more than $6 \mathrm{~mm}$. from the septum. On further examination, the pathologists from the Department of Veteri- nary Science could not confirm a diagnosis of $\mathrm{AR}$ since the turbinates were intact and by gross pathology complete. The two suspects were littermates.

Fifty-two of 60 pigs in Experiment 3 were inspected for AR. Only one pig on Diet M was considered suspect for AR. Again, the pathologists did not confirm a diagnosis of $A R$.

\section{Discussion}

The results of the experiments reported herein indicate that calcium and phosphorus levels do not adversely affect daily gain when calcium is near the N.R.C. (1964) requirements or below. Other researchers (Combs et al., 1962; Pond et al., 1964; Johnson et al., 1962; Zimmerman et al., 1960) found that as dietary calcium increases, gain decreases.

In the second experiment, BKS was significantly higher in diets with calcium at $0.65 \%$ than at $0.35 \%$ of the diet. These findings agree with Chapman et al. (1962) and Zimmerman et al. (1960) who found bone calcification higher with higher levels of calcium.

The results of the third experiment showed that increasing phosphorus in $0.10 \%$ increments from $0.30 \%$ to $0.70 \%$ of the diet had an effect $(\mathrm{P}<.10)$ on daily gain. Feed intake and BKS were also significantly $(\mathrm{P}<.005)$ increased. These observations confirm earlier work by Chapman et al. (1962) that phosphorus has a greater influence on BKS and percent bone ash than calcium within adequate levels of calcium. They found, however, that the calcium-phosphorus ratio was more important than level of phosphorus. 
TABLE 4. EFFECT OF LEVELS OF INORGANIC PHOSPHORUS ON GAIN, FEED CONVERSION AND BONE CHARACTERISTICS OF G-F SWINE

\begin{tabular}{|c|c|c|c|c|c|}
\hline \multirow[b]{2}{*}{ Treatments } & \multicolumn{5}{|c|}{ Experiment 3} \\
\hline & K & $\mathrm{L}$ & M & $\mathrm{N}$ & 0 \\
\hline $\begin{array}{l}\mathrm{Ca}, \% \\
\mathrm{P}, \% \\
\text { Inorganic } \mathrm{P}, \% \text { of total }\end{array}$ & $\begin{array}{l}0.35 \\
0.30 \\
0\end{array}$ & $\begin{array}{l}0.35 \\
0.40 \\
25\end{array}$ & $\begin{array}{r}0.35 \\
0.50 \\
40\end{array}$ & $\begin{array}{l}0.35 \\
0.60 \\
50\end{array}$ & $\begin{array}{l}0.35 \\
0.70 \\
57\end{array}$ \\
\hline No. pigs per treatment a & 12 & 12 & 12 & 12 & 12 \\
\hline \multicolumn{6}{|l|}{ Criterion } \\
\hline $\begin{array}{l}\text { Av. daily gain, kg. } \\
\text { Feed intake, kg./day } \\
\text { Gain/feed }\end{array}$ & $\begin{array}{r}.64 \\
2.18 \\
.29\end{array}$ & $\begin{array}{r}.67 \\
2.25 \\
.30\end{array}$ & $\begin{array}{r}.69 \\
2.39 \\
.28\end{array}$ & $\begin{array}{r}.72 \\
2.49 \\
.29\end{array}$ & $\begin{array}{r}.70 \\
2.42 \mathrm{c} \\
.29\end{array}$ \\
\hline $\begin{array}{l}\text { Bone breaking strength } \\
\mathrm{kg} . / \mathrm{cm}^{2} \\
\text { Bone wt., gm. } \\
\text { Bone ash, } \%\end{array}$ & $\begin{array}{r}9.6 \\
9.9 \\
57.4\end{array}$ & $\begin{array}{l}14.5 \\
12.3 \\
59.1\end{array}$ & $\begin{array}{l}11.8 \\
12.0 \\
58.7\end{array}$ & $\begin{array}{l}15.0 \\
12.4 \\
58.5\end{array}$ & $\begin{array}{l}13.8^{\mathrm{d}} \\
11.8 \\
58.9\end{array}$ \\
\hline
\end{tabular}

: Exp. 3: Two reps, 6 pigs/pen; int. wt., $24.4 \mathrm{~kg}$.

b Linear effect of phosphorus levels sig. $P<.10$.

c Linear effect of phosphorus levels sig. $\mathrm{P}<.005$

l Over-all treatment effect sig. $\mathrm{P}<.05$

Linear effect of phosphorus levels sig. $P<.10$

The increase of gain response to inorganic phosphorus is in agreement with Chapman et al. (1955) who found a significant increase in daily gain of pigs fed inorganic phosphorus. They concluded the growing-finishing pig did not utilize plant phosphorus as efficiently as inorganic phosphorus.

Brown et al. (1966) studied levels of calcium and phosphorus and its relationship to $\mathrm{AR}$ in swine. They found that levels of calcium and phosphorus under $1.0 \%$ of the diet greatly increased the incidence of AR. In the study reported herein, only three of 156 pigs examined were suspect for AR and none could definitely be classified as exhibiting AR. This observation is not in agreement with Brown et al. (1966) who concluded that the N.R.C. recommendations did not provide the protection against $A R$ that higher calcium and phosphorus levels did, since the pigs used were never fed diets which exceeded the N.R.C. requirements for calcium and phosphorus prior to being placed on test.

Lindley (1967) reported no relationship between calcium-phosphorus and AR in swine. The studies reported herein are in agreement with his findings.

\section{Summary}

Three experiments were conducted with a total of 190 Yorkshire $\times$ Hampshire crossbred pigs (initial weight 35.0, 27.4 and 22.4 $\mathrm{kg}$. for Experiments 1,2 and 3 respectively) to determine the effect of dietary levels and

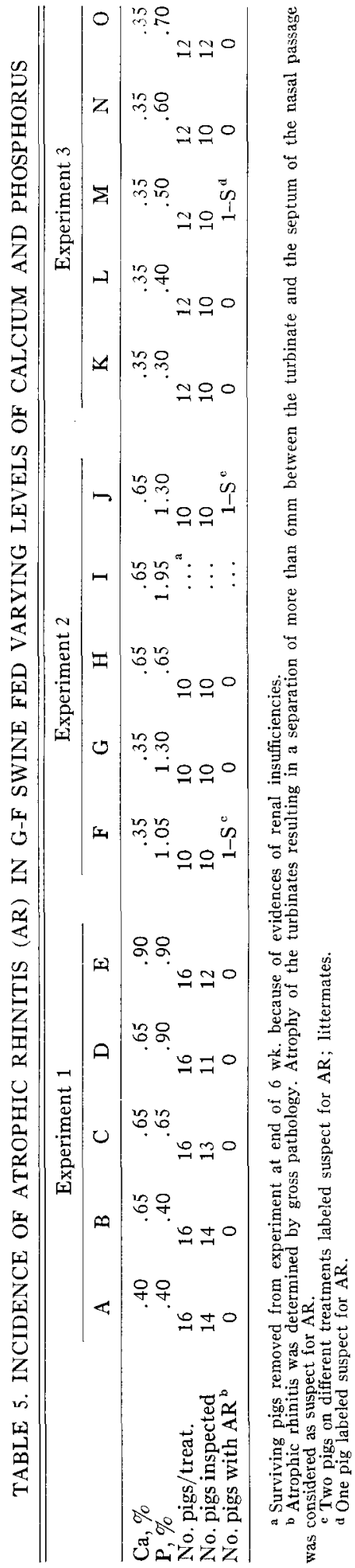


ratios of calcium and phosphorus on gain, feed intake, feed conversion, bone weight, bone breaking strength (BKS), percent bone ash and incidence of atrophic rhinitis (AR) in growing-finishing swine.

There were no significant differences in average daily gain, feed intake or feed conversion due to variation in dietary calcium or phosphorus levels in Experiment 1. BKS was significantly $(\mathrm{P}<.005)$ higher for the high level of phosphorus and interrelated level of calcium (Diet D). Experiment 2 showed an over-all significant $(\mathrm{P}<.005)$ difference in BKS and bone weight due to experimental treatment. BKS and bone weight were also significantly $(\mathrm{P}<.005)$ higher in pigs fed diets with $0.65 \%$ calcium than for those fed $0.35 \%$. BKS and bone weight had a correlation of $0.82 \%$ for Experiment 2 .

In a third experiment, pigs were fed diets varying in levels of phosphorus and amounts of inorganic phosphorus. Increasing phosphorus in equal increments from $0.30 \%$ to $0.70 \%$ of the diet improved average daily gain in a linear manner. Also, the linear effect of Ievels of dietary phosphorus on feed intake was significant $(\mathrm{P}<.005)$ with the highest intake at the $0.60 \%$ level.

BKS was significantly affected by dietary treatment $(\mathrm{P}<.05)$. The linear component of the effect of phosphorus levels on BKS approached significance. Bone weight followed the same trend as BKS with a correlation of 0.66 .

The results of these experiments show that calcium and phosphorus levels and ratios can vary considerably without significantly affecting daily gain and feed conversion of pigs. Levels and ratios of the two elements do affect bone formation as shown by BKS and bone weight data. In these experiments, bone weight seemed to be nearly as good a measurement of bone formation as BKS.

Within the levels and ratios of calcium and phosphorus studied, there was no relationship between dietary calicum and phosphorus and atrophic rhinitis in growing-finishing swine.

\section{Literature Cited}

A.O.A.C. 1960. Official Methods of Analysis (9th ed.). Association of Official Agricultural Chemists, Washington, D. C.

Brown, W. R., L. Krook and W. G. Pond. 1966. Atrophic rhinitis in swine. Etiology, pathogenesis, and prophylaxis. Cornell Veterinarian. Suppl. No. 1, Vol. LVI.

Chapman, H. L., Jr., J. Kastelic, G. C. Ashton and D. V. Catron. 1955. A comparison of phosphorus from different sources for growing and finishing swine. J. Animal Sci. 14:1073.

Chapman, H. L., Jr., J. Kastelic, G. C. Ashton, P. G. Hameyer, C. Y. Roberts, D. V. Catron, V. W. Hays and V. C. Speer. 1962. Calcium and phosphorus requirements of growing-finishing swine. J. Animal Sci. 21:112.

Combs, G. E. and H. D. Wallace. 1962. Growth and digestibility studies with young pigs fed various levels and sources of calcium. J. Animal Sci. $21: 734$.

Combs, G. E., T. H. Berry, H. D. Wallace and R. C. Crum, Jr. 1966. Levels and sources of vitamin D for pigs fed diets containing varying quantities of calcium. J. Animal Sci. 25:827.

Johnson, R. A., V. C. Speer, J. T. McCall and V. H. Hays. 1962. Levels of vitamin and mineral fortification in growing-finishing swine rations. J. Animal Sci. 21:1001. (Abstr.).

Lindley, C. E. 1967. Calcium-phosphorus ratios tested at Mississippi State. Hog Farm Management Vol. 4, No. 12, p. 22.

Lloyd, L. E., E. W. Crampton and D. N. Mowat. 1961. Effect of calcium-phosphorus ratio, oleanalomycin and protein level on the performance of early-weaned pigs. J. Animal Sci. 20:176.

Miller, E. R., D. E. Ullrey, C. L. Zutaut, D. A. Schmidt, E. A. Alexander, B. V. Baltzer, J. A. Hoefer and R. W. Luecke. 1962. Calcium requirement of the baby pig. J. Nutr. 77:7.

N. R. C. 1964. Nutrient Requirements of Domestic Animals, No. 2. Nutrient Requirements of Swine. National Research Council, Washington, D. C. Publication 648

Pond, W. G. and J. R. Jones. 1964. Effect of level of zinc in high calcium diets on pigs from weaning through one reproductive cycle and on subsequent growth of their offspring. J. Animal Sci. $23: 1057$

Rutledge, E. A., L. E. Hanson and R. J. Meade. 1961. A study of the calcium requirements of pigs weaned at three weeks. J. Animal Sci. 20:243.

Steel, R. G. D. and J. H. Torrie. 1960. Principles and Procedures of Statistics. McGraw-Hill Book Co., Inc. New York.

Zimmerman, D. R., V. C. Speer, D. V. Catron and V. W. Hays. 1960. Calcium studies with baby pigs. J. Animal Sci. 19:1301. 